DOI : https://doi.org/10.24123/jbt.v5i1.4453

\title{
EVALUASI PENERAPAN PSAK NO. 45 DAN PENGENDALIAN INTERNAL GEREJA DI WILAYAH SURABAYA, SIDOARJO DAN GRESIK
}

\author{
Agung Sriwardhani \\ Program Studi Akuntansi Politeknik Ubaya \\ Email : wardhani@staff.ubaya.ac.id
}

\begin{abstract}
This study aimed to evaluate the application of PSAK 45 accounting and internal control in 32 churches in the Surabaya, Sidaorjo and Gresik areas. The method used in this research was descriptive research by comparing the results of the study with existing theories. These are the results of this study. First, There is no strict separation of functional responsibilities, where the 26 churches have not separated the functions, while another 12 churches have clearly separated the responsibilities. Second, only 5 churches have implemented complete accounting records starting from the use of journals, general ledgers and financial reports produced by the church in accordance with PSAK 45.Third, the implementation of healthy practices in carrying out their duties and functions has not been implemented properly due to the small number of church administrator. Fourth, Employees do not have the appropriate quality and responsibility yet, because it is difficult to find people who are committed to doing services in the church.
\end{abstract}

Keywords: church accounting, psak 45, church finances, internal control.

\section{Pendahuluan}

Gereja merupakan organisasi keagamaan yang dalam pelaksanaan kegiatannya tergolong sebagai organisasi nirlaba. Gereja menjalankan kegiatanya dengan sumber daya terbesar yang berasal dari jemaatnya. Sebagai organisasi nirlaba sangatlah menarik dilakukan penelitian mengingat organisasi ini tidak hanya bertanggungjawab kepada jemaatnya namun juga kepada Tuhan. Fraud sangatlah mudah terjadi dikarenakan jemaat terkadang tidak merasa perlu mendapatkan pertanggung jawaban dari pengelolaan keuangan gereja. Banyak jemaat menganggap bahwa dana yang diberikan sebagai bentuk keiklasan yang diberikan ke gereja, sehingga tidak perlu dipertanggungjawabkan. Kondisi demikian dapat memicu pengelola keuangan gereja untuk melakukan fraud atau kecurangan dengan menyelewengkan dana gereja. Seperti yang terjadi di Singapura di gereja City Harvest, bendahara gereja yang bernama Chew Eng Han beserta 5 pengurus gerejanya termasuk didalamnya 2 pendetanya dinyatakan bersalah mengelapkan dana sebesar SGD 50 juta. (bbc.com, 2018). Selain itu seorang pendeta di Kecamatan Entikong, Kabupaten Sanggau, Kalimantan Barat, mengelapkan dana penganti rugi lahan Gereja Kristen Setia Indonesia (GKSI) yang terkena dampak pelebaran jalan (news.okezone.com,2019). 
Dalam penelitian yang dilakukan oleh Adi (2020: 17) menyatakan bahwa pencatatan akuntansi Gereja Jemaat Kristus Indonesia (GJKI) Ekklesia, Salatiga didasarkan pada tata cara dan aturan gereja. Gereja saat ini, GJKI hanya memiliki laporan arus kas yang dibuat oleh sekretaris gereja. Padahal, PSAK No. 45/2011 mensyaratkan pelaporan keuangan gereja, terdiri dari laporan posisi keuangan, laporan aktivitas dan laporan arus kas. Sedangkan dalam penelitian yang dilakukan oleh Loen (2020: 112) menyatakan bahwa laporan keuangan Gereja Bethany Depok hanya berupa laporan kas yang disebut dengan pencatatan kas, yang bertujuan melaporkan saldo kas di bank dan di bendahara secara periode mingguan dan direkap dalam bulanan. Sistem pencatatan dan pelaporan keuangan tersebut tidak dipermasalahkan oleh jemaat sebagai pemberi sumbangan, namun ada kalanya terjadi perbedaan jumlah sumbangan yang dicatat dalam tanda terima penyerahan sumbangan dengan yang diumumkan dalam laporan mingguan kepada jemaat.

Berdasarkan uraian diatas, sangatlah menarik untuk mengevaluasi bagaimana penerapan pengendalian internal yang dilakukan digereja dan bagaimana pelaporan keuangan gereja disusun, apakah laporan keuangan gereja telah disusun sesuai dengan standar yang telah ditetapkan dalam PSAK no. 45. Untuk itu dalam penelitian ini akan di evaluasi penerapan PSAK no. 45 dan pengendalian internal beberapa gereja di wilayah Surabaya, Sidoarjo dan Gresik.

\section{Landasan Teori}

\section{Pernyataan Standar Akuntansi Keuangan (PSAK) no.45} Tujuan penyajian Laporan Keuangan Nirlaba

Berdasarkan PSAK no.45 tujuan utama penyajian laporan keuangan nirlaba adalah menyediakan informasi yang relevan untuk memenuhi kepentingan para penyumbang, anggota entitas nirlaba, kreditor, dan pihak lain yang menyediakan sumber daya bagi entitas nirlaba. Secara rinci tujuan laporan keuangan, termasuk catatan atas laporan keuangan adalah menyajikan informasi mengenai :

1. Jumlah dan sifat aset, liabilitas, dan aset neto entitas nirlaba.

2. Pengaruh transaksi, peristiwa, dan situasi lainnya yang mengubah nilai dan sifat aset neto.

3. Jenis dan jumlah arus masuk dan arus keluar sumber daya dalam satu periode dan hubungan antara keduanya.

4. Cara entitas nirlaba mendapatkan dan membelanjakan kas, memperoleh pinjaman dan melunasi pinjaman, dan faktor lainnya yang berpengaruh pada likuiditasnya.

5. Usaha jasa entitas nirlaba.

\section{Laporan Keuangan Entitas Nirlaba}

Berdasarkan PSAK no.45 laporan entitas nirlaba meliputi laporan :

1. Laporan posisi keuangan (neraca) pada akhir periode laporan, yaitu untuk menyediakan informasi mengenai asset, liabilitas, serta asset neto dan informasi mengenai hubungan diantara unsur-unsur terebut pada waktu tertentu.

2. Laporan aktivitas untuk suatu periode pelaporan, yaitu laporan aktivitas adalah menyediakan informasi mengenai :

- pengaruh transaksi dan peristiwa lain yang mengubah jumlah dan sifat aset neto.

- hubungan antar transaksi, dan peristiwa lain.

- bagaimana penggunaan sumber daya dalam pelaksanaan berbagai program atau jasa.

3. Laporan arus kas untuk suatu periode pelaporan, yaitu menyajikan informasi mengenai penerimaan dan pengeluaran kas dalam suatu periode. 


\section{Pengendalian Internal}

Mulyadi (2016:129) menjelaskan bahwa sistem pengendalian internal meliputi struktur organisasi, metode dan ukuran-ukuran yang dikoordinasikan untuk menjaga aset organisasi, mengecek ketelitian dan keandalan data akuntansi, mendorong efisiensi dan mendorong dipatuhinya kebijakan manajemen.

\section{Tujuan Pengendalian Internal}

Mulyadi (2016:129) menjelaskan bahwa tujuan sistem pengendalin internal adalah : 1. Menjaga aset organisasi. 2. Mengecek ketelitian dan keandalan data akuntansi. 3. Mendorong efisiensi. 4. Mendorong dipatuhinya kebijakan manajemen.

\section{Unsur-Unsur Pengendalian Intern}

Menurut Mulyadi (2016:164) menjelaskan bahwa unsur-unsur pokok sistem pengendalian intern meliputi empat unsur besar yang tiap pointnya tidak dapat dipisahan, keempat unsur tersebut adalah:

1. Struktur organisasi yang memisahkan tanggung jawab fungsional secara tegas.

2. Sistem wewenang dan prosedur pencatatan yang memberikan perlindungan yang cukup terhadap kekayaan, pendapatan dan biaya.

3. Praktik yang sehat dalam melaksankan tugas dan fungsi setiap unit organisasi.

4. Karyawan yang mutunya sesuai dengan tanggungjawabnya

Sedangkan prinsip-prinsip pengendalian intern meliputi :

1. Pemisahan fungsi.

2. Prosedur pemberian wewenang.

3. Prosedur dokumentasi.

4. Prosedur dan catatan akuntansi.

5. Pengawasan fisik.

6. Pemeriksaan intern secara bebas.

\section{Penelitian Terdahulu}

Mamesha (2013) dalam penelitiannya menyatakan bahwa gereja GMIM Efrata Sentrum Sonder belum menerapkan PSAK No. 45 baik ditinjau dari segi format maupun penyusunan laporan keuangannya, selain itu gereja GMIM Efrata Sentrum Sonder juga belum memiliki kualitas informasi yang baik dalam menyajikan informasi yang relevan, andal dan mudah dipahami oleh jemaat. Dalam penelitiannya Mamaesha menyesuaikan laporan keuangan gereja GMIM Efrata Sentrum Sonder dengan penerapan PSAK no. 45.

Sedangkan menurut Wonok (2016) hasil dari penelitiannya di jemaat GMIM Imanuel Leilem menyatakan bahwa gereja belum menerapkan PSAK No. 45 tentang pelaporan keuangan entitas nirlaba pada laporan keuangannya, dan menggunakan laporan keuangan yang disetujui bersama oleh organisasi gereja. Sebaiknya Jemaat GMIM Imanuel Leilem menerapkan pedoman PSAK No. 45 agar kualitas laporan keuangan lebih baik dan lebih jelas, serta melakukan kajian dan pelatihan dalam menerapkan PSAK No.45.

Penelitian yang dilakukan Tjungadi, dkk (2020) menyatakan bahwa pelaksanaan akuntabilitas pelaporan keuangan gereja belum berjalan dengan optimal. Pengendalian internal pun belum berjalan dengan baik, terutama pengurus keuangan gereja yang kurang kompeten, pemisahan tugas yang belum sepenuhnya baik, dan penerapan pedoman umum yang belum optimal. Kurangnya pemahaman para pengurus keuangan juga dimaklumi oleh jemaat, sehingga menerima saja keadaan tersebut. Pedoman umum pengelolaan 
keuangan dan harta milik Gereja Toraja sebaiknya diperbaiki dan meningkatkan sosialisasi kepada para pengurus keuangan dan majelis jemaat.

\section{Metode Penelitian \\ Jenis Penelitian}

Jenis penelitian yang digunakan dalam penelitian ini adalah penelitian deskriptif yaitu mendeskripsikan kondisi gereja dalam menerapkan akuntansi gereja sesuai dengan PSAK 45 dan pengendalian internal gereja.

\section{Prosedur Penelitian}

Prosedur penelitian yang digunakan adalah

1. Penentuan objek penelitian, dalam penelitian ini objek penelitian terdiri dari 32 gereja diwilayah Surabaya, Sidoarjo dan Gresik. Berikut data gereja yang dijadikan objek penelitian:

Tabel 1

Daftar Gereja Objek Penelitian

\begin{tabular}{|c|c|c|c|c|c|c|c|}
\hline No & Gereja & No & Gereja & No & Gereja & No & Gereja \\
\hline 1 & $\begin{array}{l}\text { GBI Blessing Center } \\
\text { Surabaya }\end{array}$ & 9 & GBI Waru Sidoarjo & 17 & GKI Manyar Surabaya & 25 & HKBD Sidoarjo \\
\hline 2 & GBI Centro Sidaorjo & 10 & $\begin{array}{l}\text { GBT Gosyen Blessing } \\
\text { Surabaya }\end{array}$ & 18 & GKI Naggel Surabaya & 26 & $\begin{array}{l}\text { Persekutuan Warga } \\
\text { Oikumene Juanda }\end{array}$ \\
\hline 3 & $\begin{array}{lr}\text { GBI } & \text { Diaspora } \\
\text { Sejahtera Surabaya }\end{array}$ & 11 & $\begin{array}{l}\text { GBT } \quad \text { Kristus } \\
\text { Gembalaku Surabaya }\end{array}$ & 19 & $\begin{array}{l}\text { GKI } \\
\text { Surabaya }\end{array}$ & 27 & $\begin{array}{l}\text { Santa Maria Tak } \\
\text { Bercela Surabaya }\end{array}$ \\
\hline 4 & $\begin{array}{l}\text { GBI Dupak Jaya } \\
\text { Surabaya }\end{array}$ & 12 & $\begin{array}{lr}\text { Gereja } & \text { Kristen } \\
\text { Reformasi } & \text { Indonesia } \\
\text { Surabaya } & \end{array}$ & 20 & $\begin{array}{l}\text { GKJW Jemaat } \\
\text { Gubeng Surabaya }\end{array}$ & 28 & $\begin{array}{l}\text { Santo } \\
\text { Sidoarjo }\end{array}$ \\
\hline 5 & $\begin{array}{l}\text { GBI Gestsemani } \\
\text { Victorious Success }\end{array}$ & 13 & $\begin{array}{l}\text { Gereja Kristus Raja } \\
\text { Surabaya }\end{array}$ & 21 & $\begin{array}{l}\text { GKJW Jemaat Karang } \\
\text { Pilang Surabaya }\end{array}$ & 29 & $\begin{array}{l}\text { ST. Aloysius } \\
\text { Gonzaga Surabaya }\end{array}$ \\
\hline 6 & $\begin{array}{l}\text { GBI Kristus Gembala } \\
\text { Agung Surabaya }\end{array}$ & 14 & $\begin{array}{l}\text { Gereja Pantekosta di } \\
\text { Indonesia Surabaya }\end{array}$ & 22 & $\begin{array}{l}\text { GKJW Jemaat Ngagel } \\
\text { Surabaya }\end{array}$ & 30 & $\begin{array}{lr}\text { Gereja } & \text { Gembala } \\
\text { Yang } & \text { Baik } \\
\text { Surabaya } & \end{array}$ \\
\hline 7 & $\begin{array}{l}\text { GBI Rock } \text { Candi } \\
\text { Sidoarjo }\end{array}$ & 15 & Pantekosta & 23 & GKKA Sidoarjo & 31 & $\begin{array}{l}\text { Gereja } \quad \text { Toraja } \\
\text { Jemaat Surabaya }\end{array}$ \\
\hline 8 & GBI Rock Surabaya & 16 & $\begin{array}{l}\text { Gereja Sakramen } \\
\text { Mahakudus Surabaya }\end{array}$ & 24 & GPDI Elotim Sidoarjo & 32 & $\begin{array}{l}\text { Gereja Toraja } \\
\text { Jemaat Sidoarjo }\end{array}$ \\
\hline
\end{tabular}

2. Persiapan penelitian, dalam penelitian ini persiapan penelitian meliputi penyusunan proposal dan mengurus dokumen yang diperlukan termasuk surat pengantar dan isi melakukan wawancara.

3. Pengumpulan data, dalam penelitian ini pengumpulan data dilakukan di 32 gereja sebagai objek penelitian.

4. Analisis, yaitu menganalisis dan meneliti hasil data yang telah ada.

5. Kesimpulan yaitu memberikan kesimpulan dari hasil penelitian yang dilakukan dengan membandingkan teori yang ada.

\section{Metode Analisis}

Metode analisis dalam penelitian ini mengali 4 isu terkait dengan perlakukan akuntansi gereja yaitu :

1. Analisis perlakuan akuntansi di gereja, yang terdiri dari :

a. Profile pengelola keuangan gereja.

b. Pencatatan dan sistem pengendalian internal keuangan gereja.

c. Penerapan Pernyataan Standar Akuntansi Keuangan no 45 di gereja.

d. Pengelolaan keuangan gereja berbasis komputerisasi dan berbasis web.

2. Analisis hasil penelitian dengan teori terkait. 


\section{Pembahasan \\ Hasil Penelitian Analisis Perlakuan Akuntansi di Gereja. a. Analisis profile pengelola keuangan gereja.}

Profile pengelola keuangan gereja dalam penelitian ini ditinjau dari segi pendidikan, banyaknya staff pengelola keuangan gereja serta pemahaman mengenai tugas dan fungsi bagian keuangan/bendahara gereja. Berdasarkan hasil wawancara pada 32 gereja menyatakan bahwa pendidikan staff pengurus gereja bervariasi mulai dari level SMP sampai dengan sarjana. Namun demikian profile pengelola keuangan gereja biasanya didasarkan pada kesediaan masing masing pribadi dalam memberikan pelayanan kepada gereja. Sehingga gereja tidak dapat memaksa seseorang untuk menjadi pengelola keuangan gereja. Hal yang dilakukan gereja adalah menawarkan kepada jemaat terkait kosongnya pengelolan keuangan gereja. Apabila terdapat jemaat yang bersedia maka akan disetujui dan kemudian diteguhkan dalam rapat majelis ataupun rapat pengurus gereja disaksikan seluruh jemaat.

Ditinjau dari segi pendidikan sebagian besar pengelola keuangan gereja telah memiliki pendidikan sarjana, namun demikian latar belakang pendidikan diploma/sarjana masih bevariasi, belum sepenuhnya berpendidikan akuntansi atau berasal dari SMK akuntansi. Hal tersebut menunjukkan bahwa meskipun pengelola keuangan gereja telah memiliki latar belakang mendidikan diploma/sarjana namun belum sepenuhnya memahami mengenai konsep akuntansi dan pengelolaan keuangan yang benar sesuai dengan PSAK 45.

Ditinjau dari segi jumlah staff pengelola keuangan banyak gereja beranggapan bahwa jumlah pengelolaan keuangan gereja tidak membutuhkan banyak staff karena pengeluaran gereja yang dianggap hanya sederhana sehingga tidak membutuhkan banyak orang untuk mengurusnya maupun melakukan pencatatan keuangan gereja. Namun demikian terdapat pendapat juga bahwa kesulitan yang dialami gereja untuk mencari staff pengelola keuangan gereja yang benar benar mau memberikan waktunya untuk pelayanan, banyak orang yang pandai didalam gereja, namun belum tentu ada jemaat mau memberikan waktu dan hatinya untuk memberikan pelayanan dalam bidang keuangan.

Ditinjau dari segi pemahaman mengenai fungsi dan peran bagian keuangan/bendahara gereja, beberapa gereja menyampaikan bahwa pengelola keuangan/bendahara seharusnya juga menyusun anggaran kas. Namun terdapat juga pendapat yang menyatakan bahwa pengelola keuangan gereja/bendahara gereja seharusnya hanya mencatat penerimaan dan pengeluaran kas saja, sedangkan anggaran kas seharusnya disusun oleh tim khusus atau yang disebut tim perancang yang terdiri dari berbagai bagian/sie yang menyampaikan setiap anggaran pada masing masing kegiatan. Setelah anggaran tersebut disetujui dalam rapat Majelis/Rapat Urusan Gereja harus mendapatkan persetujuan dari seluruh jemaat.

Berikut hasil wawancara pada 32 gereja terkait dengan analisis profile gereja :

\section{Profile pendidikan pengelola keuangan gereja.}

Tabel 2

Pendidikan Pengelola Gereja

\begin{tabular}{|c|c|c|}
\hline Pendidikan & Jumlah & Prosentase \\
\hline Sarjana & 24 & $73 \%$ \\
\hline SMA & 6 & $18 \%$ \\
\hline
\end{tabular}




\begin{tabular}{|c|c|c|}
\hline Sarjana, SMA & 2 & $6 \%$ \\
\hline SMA, SMP & 1 & $3 \%$ \\
\hline Total & 33 & $100 \%$ \\
\hline
\end{tabular}

Profile pengelolan keuangan 24 gereja telah berpendidikan sarjana, 6 gereja lainnya berpendidikan SMA/SMK dan bahkan 1 gereja menyatakan bahwa pengelola keuangan gereja mereka masih ada yang level SMP dan SMA/SMK.

\section{Jumlah staff pengelolan keuangan di dalam gereja.}

Tabel 3

Jumlah Staff Pengelola Keuangan Gereja

\begin{tabular}{|c|c|c|}
\hline $\begin{array}{c}\text { Jumlah Pengelola } \\
\text { Keuangan Gereja }\end{array}$ & Jumlah & Prosentase \\
\hline $2-5$ orang & 28 & $88 \%$ \\
\hline 5-10 orang & 2 & $6 \%$ \\
\hline$>10$ orang & 2 & $6 \%$ \\
\hline Total & $\mathbf{3 2}$ & $\mathbf{1 0 0 \%}$ \\
\hline
\end{tabular}

Jumlah pengelola keuangan gereja hanya butuh 2-5 orang disampaikan 28 gereja, sedangkan 4 gereja lainnya menyatakan bahwa dibutuhkan $>5$ orang staff pengelola gereja.

\section{Tugas dan fungsi bagian keuangan/bendahara gereja}

Tabel 4

Tugas dan Fungsi Bagian Keuangan Gereja

\begin{tabular}{|c|c|c|}
\hline Tugas dan Fungsi Bagian Keuangan Gereja & Jumlah & Prosentase \\
\hline $\begin{array}{l}\text { Menyusun Anggaran kas dan Mencatat semua } \\
\text { penerimaan dan pengeluaran gereja }\end{array}$ & 24 & $75 \%$ \\
\hline $\begin{array}{l}\text { Mencatat semua penerimaan dan pengeluaran } \\
\text { gereja }\end{array}$ & 8 & $25 \%$ \\
\hline Total & 32 & $100 \%$ \\
\hline
\end{tabular}

Tugas dan fungsi bagian keuangan gereja seharusnya tidak hanya mencatat penerimaan dan pengeluaran saja namun juga membantu penyusunan anggaran kas gereja dinyatakan 24 gereja, sedangkan 8 gereja lainnya menyatakan tugas dan fungi bagian keuangan gereja hanya mencatat penerimaan dan pengeluaran gereja saja.

\section{b. Analisis pencatatan dan sistem pengendalian keuangan gereja}

Analisis pencatatan dan sistem keuangan gereja dalam penelitian ini ditinjau dari beberapa aspek yaitu dari segi pengendalian intern keuangan yang lakukan digereja dengan melihat siapa saja yang menyetujui anggaran gereja, pengeluaran dan penerimaan kas gereja. Yang kedua dari segi pembukuannya yang meliputi dokumen dan catatan akuntansi yang digunakan serta laporan yang dihasilkan dalam keuangan gereja.

Ditinjau dari segi pengendalian internal gereja, pada dasarnya pengendalian internal sangatlah penting bagi suatu organisasi. Pengendalian internal yang tidak baik rentan menimbulkan banyak kesalahan, kolusi, management overrates serta dapat memberikan penilaian yang salam dalam pengambilan keputusan. Dalam penelitian ini pengendalian internal salah satunya dilihat dari otorisasi dan persetujuan anggaran serta otorisasi penerimaan dan pengeluaran kas. Berdasarkan hasil wawancara beberapa gereja 
menyatakan bahwa penyusunan anggaran telah dilakukan oleh tim tersendiri yang khusus untuk menyusun anggaran gereja, biasanya penyusunan anggaran sesuai dengan kebutuhan di masing masing sie kegiatan, setelah anggaran tersebut tersusun akan disampaikan dalam rapat majelis atau dalam rapat urusan gereja dan disahkan oleh seluruh jemaat. Namun demikian masih terdapat gereja dimana pendeta memiliki otorisasi penuh dan menyetujui seluruh kegiatan yang telah dilakukan didalam gereja. Begitu pula dalam otorisasi penerimaan dan pengeluaran keuangan gereja, beberapa gereja menyatakan bendahara gereja dan majelis gereja memiliki otorisasi dalam pengeluaran dan penerimaan keuangan gereja.

Ditinjau dari segi proses dan pencatatan akuntansi keuangan beberapa gereja telah menggunakan bukti pendukung dalam proses pelaporan transaksi keuangan gereja, seperti misalnya nota, kuitansi dan lainnya. Beberapa gereja menyatakan untuk pengeluaran kas harus disertai dengan proposal dan surat pangajuan anggaran dan mendapatkan persetujuan dari bendahara maupun majelis gereja, dan untuk pelaporan keuangan harus mengetahui seluruh jemaat gereja. Pertanggungjawaban bisa dilakukan setiap minggu maupun dalam rapat khusus. Dana kas yang masuk dari jemaat disampaikan kepada jemaat setiap minggunya dalam buletin mingguan gereja. Namun demikian masih terdapat gereja yang hanya menggunakan pencatatan kas keluar dan kas masuk saja, tanya meminta pengembalian bukti transaksi seperti nota, kuitansi dan lainya.

Dalam proses akuntansi masih banyak sekali gereja yang belum menerapkan akuntansi dengan benar. Sebagian besar gereja hanya menggunakan jurnal pengeluaran dan penerimaan kas saja. Hanya 5 gereja yang menerapkan pencatatan akuntansi secara lengkap mulai dari penggunaan jurnal, buku besar juga dalam hal laporan yang dihasilkan gereja dengan lengkap sesuai PSAK 45 yaitu laporan aktivitas, laporan arus kas dan neraca.

Berikut hasil wawancara pada 32 gereja terkait dengan analisis pencatatan dan sistem pengendalian keuangan gereja :

\section{Pihak yang memiliki otorisasi dan menyetujui anggaran gereja}

Tabel 5

Otorisasi dan Persetujuan Anggaran Gereja

\begin{tabular}{|l|c|c|}
\hline \multicolumn{1}{|c|}{$\begin{array}{c}\text { Pihak Yang Memiliki Otorisasi dan } \\
\text { Menyetujui Anggaran Gereja }\end{array}$} & Jumlah & Prosentase \\
\hline Bendahara Gereja & 1 & $3 \%$ \\
\hline Majelis Gereja & 14 & $44 \%$ \\
\hline Pendeta & 7 & $22 \%$ \\
\hline Bendahara Gereja dan Pendeta & 2 & $6 \%$ \\
\hline Majelis Gereja dan Pendeta & 2 & $6 \%$ \\
\hline $\begin{array}{l}\text { Bendahara Gereja, Pendeta dan Panitia } \\
\text { Perancang Anggaran }\end{array}$ & 1 & $3 \%$ \\
\hline \begin{tabular}{l} 
Lainnya : $\begin{array}{l}\text { Panitia Perancang Anggaran (PPA) } \\
\text { Ketua Bidang Anggaran } \\
\text { Total }\end{array}$ \\
\hline \multicolumn{1}{|c|}{}
\end{tabular} & $16 \%$ \\
\hline
\end{tabular}


Otorisasi dan menyetujui anggaran gereja dilakukan oleh majelis gereja dinyatakan oleh 14 gereja, 7 lainnya dilakukan oleh Pendeta dan 11 lainnya dilakukan oleh Panitia Perancang Anggaran atau Ketua Bidang dan persetujuan yang lainnya.

\section{Pihak yang melakukan otorisasi dan menyetujui penerimaan dan pengeluaran} kas gereja

Tabel 6

Otorisasi dan Persetujuan Penerimaan/engeluaran Kas

\begin{tabular}{|l|c|c|}
\hline $\begin{array}{l}\text { Pihak Yang Melakukan Otorisasi dan Menyetujui } \\
\text { Penerimaan dan Pengeluaran Gereja }\end{array}$ & Jumlah & Prosentase \\
\hline Bendahara Gereja & 9 & $28 \%$ \\
\hline Majelis Gereja & 9 & $28 \%$ \\
\hline Pendeta & 7 & $22 \%$ \\
\hline Bendahara Gereja dan Pendeta & 3 & $9 \%$ \\
\hline Bendahara Gereja dan Majelis & 1 & $3 \%$ \\
\hline $\begin{array}{l}\text { Lainnya: } \\
\text { - Ketua Bidang } \\
\text { - Petugas yang bertanggungjawab terhadap anggaran }\end{array}$ & 3 & $9 \%$ \\
\hline Total & & \\
\hline
\end{tabular}

Otorisasi dan menyetujui penerimaan dan pengeluaran gereja dilakukan oleh bendahara gereja atau ketua bendahara dinyatakan 9 gereja, 9 lainnya menyatakan dilakukan oleh majelis gereja, 7 lainnya dilakukan oleh pendeta dan 7 lainnya dilakukan lebih dari 1 pihak.

\section{Dokumen yang digunakan dalam proses keuangan digereja}

Tabel 7

Dokumen Keuangan Gereja

\begin{tabular}{|c|c|c|}
\hline $\begin{array}{c}\begin{array}{c}\text { Dokumen yang digunakan dalam proses keuangan } \\
\text { gereja }\end{array} \\
\end{array}$ & Jumlah & Prosentase \\
\hline $\begin{array}{l}\text { Bukti Kas Masuk, Kas Keluar } \\
\text { (Buku Kas Gereja) }\end{array}$ & 7 & $22 \%$ \\
\hline $\begin{array}{l}\text { Bukti Kas Masuk, Kas Keluar } \\
\text { (Buku Kas Gereja) dan Nota/Memo }\end{array}$ & 19 & $59 \%$ \\
\hline $\begin{array}{l}\text { Bukti Kas Masuk, Kas Keluar } \\
\text { (Buku Kas Gereja), Nota/Memo dan dokumen yang } \\
\text { lainnya: } \\
\text { - Surat Pengajuan Kegiatan } \\
\text { - Surat Permohonan Keuangan } \\
\text { - Proposal } \\
\text { - LPJ (Laporan Pertanggung Jawaban Kegiatan) } \\
\text { - Mutasi rekening Bank }\end{array}$ & 6 & $19 \%$ \\
\hline Total & 32 & $100 \%$ \\
\hline
\end{tabular}

Berdasarkan hasil wawancara menunjukkan bahwa 7 gereja hanya menggunakan dokumen kas masuk dan kas kelua, 19 gereja lainnya menyatakan telah menggunakan dokumen kas masuk, ks keluar dan dokumen lain dan 6 gereja lainnya sangat lengkap telah menggunakan bukti kas masuk, kas keluar, memo, nota dan dokumen lain seperti proposal, surat pengajuan kegiatan maupun pengajuan kas. 
4. Catatan akuntansi yang digunakan dalam sistem keuangan gereja

Tabel 8

Catatan Akuntansi yang Digunakan Dalam Sistem Keuangan Gereja

\begin{tabular}{|l|c|c|}
\hline $\begin{array}{l}\text { Catatan Akuntansi Yang Digunakan Dalam Proses } \\
\text { Keuangan Gereja }\end{array}$ & Jumlah & Prosentase \\
\hline Jurnal Penerimaan, Jurnal Pengeluaran & 8 & $25 \%$ \\
\hline Jurnal Penerimaan, Jurnal Pengeluaran dan Buku Besar & 11 & $34 \%$ \\
\hline Buku Besar & 6 & $19 \%$ \\
\hline $\begin{array}{l}\text { Buku Besar dan Lainnya : } \\
\text { - Program Kegiatan Tahunan } \\
\text { - Laporan Keuangan Bulanan }\end{array}$ & 2 & $6 \%$ \\
\hline $\begin{array}{l}\text { Jurnal Penerimaan, Jurnal Pengeluaran , Buku Besar dan } \\
\text { Lainnya: } \\
-\quad \text { Program Kegiatan Tahunan } \\
\text { Laporan Keuangan Bulanan }\end{array}$ & 5 & $16 \%$ \\
\hline \multicolumn{1}{|c|}{ Total } & $\mathbf{3 2}$ & $\mathbf{1 0 0 \%}$ \\
\hline
\end{tabular}

Berdasarkan hasil wawancara menunjukkan bahwa 8 gereja hanya menggunakan dokumen kas masuk dan kas keluar, 11 gereja lainnya menyatakan telah menggunakan dokumen kas masuk, ks keluar dan dokumen lain dan 7 gereja lainnya sangat lengkap telah menggunakan bukti kas masuk, kas keluar, memo, nota dan dokumen lain seperti proposal, surat pengajuan kegiatan maupun pengajuan kas.

5. Laporan yang dihasilkan dalam sistem keuangan digereja.

Tabel 9

Laporan yang Dihasilkan dari Sistem Keuangan Gereja

\begin{tabular}{|c|c|c|}
\hline $\begin{array}{l}\text { Laporan yang Dihasilkan dari Sistem Keuangan } \\
\text { Gereja }\end{array}$ & Jumlah & Prosentase \\
\hline Laporan Aktivitas & 5 & $16 \%$ \\
\hline Laporan Arus Kas & 5 & $16 \%$ \\
\hline Laporan Aktivitas dan Laporan Arus Kas & 3 & $9 \%$ \\
\hline Laporan Aktivitas dan Neraca & 9 & $28 \%$ \\
\hline Laporan Arus Kas dan Neraca & 3 & $9 \%$ \\
\hline Laporan Aktivitas, Laporan Arus Kas dan Neraca & 5 & $16 \%$ \\
\hline $\begin{array}{l}\text { Lainnya : } \\
\text { Laporan Tahunan Gereja, Buletin Gereja }\end{array}$ & 2 & $6 \%$ \\
\hline Total & 32 & $100 \%$ \\
\hline
\end{tabular}

Laporan keuangan yang lengkap hanya disusun oleh 5 gereja, sedangkan 27 gereja yang lain laporan yang disusun tidak lengkap.

\section{c. Analisis pemahaman penerapan PSAK No. 45.}

Berdasarkan hasil wawancara diketahui masih banyak gereja yang belum menerapkan akuntansi keuangan gereja sesuai PSAK no. 45. Bahkan 23 gereja menyatakan tidak mengetahui apa yang dimaksud dengan PSAK no. 45. Hanya 9 gereja yang memahami penerapan PSAK no. 45, namun belum sepenuhnya diterapkan didalam gereja. Jika dilihat dari pernyataan sebelumnya dapat dipastikan hanya sekitar 5 gereja 
yang telah menerapkan PSAK no. 45 dengan laporan keuangan dan dokumen yang lengkap digunakan gereja tersebut.

Berikut hasil wawancara pada 32 gereja terkait dengan analisis pemahaman penerapan PSAK no.45:

Tabel 10

Memahami penerapan PSAK no 45 Dalam Sistem Keuangan Gereja

\begin{tabular}{|c|c|c|}
\hline $\begin{array}{l}\text { Penerapan PSAK no } 45 \text { Dalam } \\
\text { Sistem Keuangan Gereja }\end{array}$ & Jumlah & Prosentase \\
\hline Memahami menerapkan PSAK 45 & 9 & $28 \%$ \\
\hline $\begin{array}{l}\text { Belum memahami menerapkan PSAK } \\
45\end{array}$ & 23 & $72 \%$ \\
\hline Total & 32 & $100 \%$ \\
\hline
\end{tabular}

d. Analisis pengelolaan keuangan gereja berbasis komputerisasi dan berbasis web.

Berdasarkan hasil wawancara diketahui bahwa masih banyak gereja pengelolaan keuangannya tidak berbasis komputerisasi dan tidak berbasis web. Hanya sekitar 5 gereja yang telah menggunakan komputerisasi. Sebagian gereja menggunakan excel untuk mencatat transaksi keuangan gereja mereka. Dalam wawancara terkait dengan penggunaan web dalam system komputeriasi gereja hanya 22 gereja yang menyatakan bersedia menerapkan penggunaan pencatatan akuntansi terkomputerisasi berbasis web. Alasan yang dikemukakan gereja tidak bersedia menerapkan akuntansi komputer berbasis web terkait dengan keamanan penyimpanan data gereja yang mungkin bisa diretas.

Berikut hasil wawancara pada 32 gereja terkait dengan analisis pengelolaan akuntansi berbasis komputer:

1. Sistem keuangan gereja telah terkomputerisasi

Tabel 11

Komputerisasi Sistem Keuangan Gereja

\begin{tabular}{|l|c|c|}
\hline Komputerisasi Sistem Keuangan Gereja & Jumlah & Prosentase \\
\hline Sistem Keuangan Gereja Telah Terkomputerisasi & 5 & $16 \%$ \\
\hline Sistem Keuangan Gereja Belum Terkomputerisasi & 27 & $84 \%$ \\
\hline Total & 32 & $100 \%$ \\
\hline
\end{tabular}

2. Keinginan memiliki sistem keuangan gereja berbasis web

Tabel 12

Keinginan Memiliki Sistem Keuangan Gereja Berbasis Web

\begin{tabular}{|llll|c|c|}
\hline $\begin{array}{l}\text { Keinginan Memiliki Sistem Keuangan Gereja } \\
\text { Berbasis Web }\end{array}$ & Jumlah & Prosentase \\
\hline $\begin{array}{l}\text { Ingin merubah } \\
\text { Terkomputerisasi }\end{array}$ & Sistem & Keuangan Gereja & 20 & $53 \%$ \\
\hline $\begin{array}{l}\text { Tidak ingin Sistem } \\
\text { Terkomputerisasi }\end{array}$ & Keuangan Gereja & 18 & $47 \%$ \\
\hline \multicolumn{70}{|c|}{ Total } & 32 & $100 \%$ \\
\hline
\end{tabular}




\section{Analisis Perbandingan Hasil Penelitian dengan Teori a. Praktek pengendalian internal yang dapat diterapkan di dalam gereja}

Karakteristik dan budaya masing masing gereja pada dasarnya berbeda, sehingga pengendalian internal gereja seharusnya disesuaikan dengan kondisi masing masing gereja. Dalam penelitian ini pengendalian internal yang diterapkan mengacu pada teori Mulyadi yang menyatakan bahwa pengendalian internal terdiri 4 point penting yaitu :

1. Terdapat pemisahan organisasi dan tanggung jawab fungsional secara tegas

2. Terdapat system wewenang dan prosedur pencatatan yang memberikan perlindungan yang cukup terhadap asset organisasi

3. Terdapat praktek yang sehat dalam melaksanankan tugas dan fungsi setiap organisasi

4. Terdapat karyawan yang memiliki mutu dan tanggung jawab yang sesuai.

Berikut adalah tabel perbandingan sistem penegnadalian Internal gereja:

\section{Tabel 13}

Perbandingan hasil Penelitian dan perbaikan Sistem Pengendalian Internal geraja

\begin{tabular}{|c|c|c|}
\hline No & Teori & asil penelitian \\
\hline 1 & $\begin{array}{lr}\text { Terdapat } & \text { pemisahan } \\
\text { organisasi } & \text { dan } \\
\text { tanggung } & \text { jawab } \\
\text { fungsional } & \text { secara } \\
\text { tegas } & \end{array}$ & $\begin{array}{l}\text { Pemisahan organisasi dan tanggung jawab yang tegas belum } \\
\text { diterapkan pada organisasi gereja. Hasil wawancara } 26 \text { gereja } \\
\text { menyatakan bahwa tugas dan fungsi bagian keuangan gereja } \\
\text { seharusnya tidak hanya mencatat penerimaan dan pengeluaran saja } \\
\text { namun juga penyusunan anggaran kas gereja, sedangkan } 12 \text { gereja } \\
\text { lainnya menyatakan bahwa tugas dan fungi bagian keuangan gereja } \\
\text { hanya mencatat penerimaan dan pengeluaran gereja saja dimana } \\
\text { penyusunan anggarn terpisah dari peran bagian keuangan gereja }\end{array}$ \\
\hline 2 & $\begin{array}{l}\text { Terdapat } r \text { sistem } \\
\text { wewenang dan } \\
\text { prosedur pencatatan } \\
\text { yang memberikan } \\
\text { perlingkungan yang } \\
\text { cukup terhadap asset } \\
\text { organisasi }\end{array}$ & $\begin{array}{l}\text { Dalam proses akuntansi masih banyak sekali gereja yang belum } \\
\text { menerapkan akuntansi dengan benar. Sebagian besar gereja hanya } \\
\text { menggunakan jurnal pengeluaran dan penerimaan kas saja. Hanya } 5 \\
\text { gereja yang menerapkan pencatatan akuntansi secara lengkap mulai } \\
\text { dari penggunaan jurnal, buku besar juga laporan keuangan yang } \\
\text { dihasilkan gereja sesuai PSAK } 45 \text {. }\end{array}$ \\
\hline 3 & $\begin{array}{l}\text { Terdapat praktek yang } \\
\text { sehat dalam } \\
\text { melaksanankan tugas } \\
\text { dan fungsi setiap } \\
\text { organisasi }\end{array}$ & $\begin{array}{l}\text { Berdasarkan hasil wawancara } 15 \text { gereja menyatakan otorisasi dan } \\
\text { menyetujui anggaran gereja dilakukan oleh majelis gereja, } 8 \text { lainnya } \\
\text { dilakukan oleh Pendeta dan } 9 \text { lainnya dilakukan oleh Panitia } \\
\text { Perancang Anggaran atau Ketua Bidang. Hal tersebut menjelaskan } \\
\text { bahwa pelaksanaan praktek yang sehat dalam organisasi gereja juga } \\
\text { belum sepenuhnya dilaksanakan karena masih tercampurnya peran } \\
\text { dan tugas pada masing masing fungsi atau bagian. Selain itu } \\
\text { sedikitnya jumlah pengelola keuangan menyebabkan sulitnya } \\
\text { praktek yang sehat dilaksanakan, } 34 \text { gereja menyatakan hanya } \\
\text { butuh 2-5 orang staff saja untuk mengelola keuangan gereja. } \\
\text { Sedangkan } 4 \text { gereja lainnya menyatakan membutuhkan }>5 \text { orang } \\
\text { staff pengelola gereja. }\end{array}$ \\
\hline 4 & $\begin{array}{l}\text { Terdapat karyawan } \\
\text { yang memiliki mutu } \\
\text { dan tanggung jawab } \\
\text { yang sesuai. }\end{array}$ & $\begin{array}{l}\text { Ditinjau dari segi mutu karyawan menunjukkan } 29 \text { gereja } \\
\text { menyatakan pendidikan pengelola keuangan gereja sarjana, namun } \\
\text { demikian latar belakang pendidikan diploma/sarjana masih } \\
\text { bevariasi, belum sepenuhnya berpendidikan akuntansi atau berasal } \\
\text { dari SMK akuntansi. Hal tersebut menunjukkkan bahwa meskipun } \\
\text { pengelola keuangan gereja telah memiliki latar belakang }\end{array}$ \\
\hline
\end{tabular}




\begin{tabular}{|l|l|l|}
\hline & $\begin{array}{l}\text { mendidikan diploma/sarjana namun belum sepenuhnya memahami } \\
\text { mengenai akuntansi dan pengelolaan keuangan yang benar. }\end{array}$ \\
\hline
\end{tabular}

b. Model Penyusunan Laporan Keuangan Gereja Berdasarkan PSAK No. 45 yang dapat diterapkan di Gereja.

\section{Tabel 14}

Perbandingan hasil Penelitian dan penerpan akuntansi berdasrkan PSAK no. 45

\begin{tabular}{|c|c|c|c|}
\hline No & Teori & Hasil penelitian & $\begin{array}{l}\text { Alternatif perbaikan } \\
\text { yang dapat dilakukan }\end{array}$ \\
\hline 1 & $\begin{array}{l}\text { Berdasarkan PSAK no. } 45 \\
\text { menyatakan bahwa laporan } \\
\text { keuangan yang dihasilkan } \\
\text { dalam organisasi nirlaba } \\
\text { seperti gereja terdiri dari : } \\
\text { 1. Laporan Aktivitas } \\
\text { 2. Laporan Arus Kas } \\
\text { 3. Neraca }\end{array}$ & $\begin{array}{l}\text { Terdapat } 29 \text { gereja tidak } \\
\text { mengetahui PSAK no. } \\
\text { 45. Hanya } 9 \text { gereja yang } \\
\text { memahami penerapan } \\
\text { PSAK no. 45, namun } \\
\text { penerapan didalam gereja } \\
\text { belum sepenuhnya sesuai } \\
\text { dengan PSAK no. } 45 . \\
\text { Sedangkan } 5 \text { gereja yang } \\
\text { lain memiliki laporan } \\
\text { keuangan lengkap sesuai } \\
\text { PSAK no. 45, yaitu } \\
\text { Laporan Aktivitas, } \\
\text { Laporan Arus Kas dan } \\
\text { Neraca. }\end{array}$ & $\begin{array}{l}\text { Contoh alternatif } \\
\text { perbaikan yang dapat } \\
\text { dilakukan adalah: } \\
\text { 1. Menyusun chat of } \\
\text { account } \\
\text { 2. Menyusun Laporan } \\
\text { Aktivitas } \\
\text { 3. Menysun Laporan } \\
\text { Arus Kas } \\
\text { 4. Neraca }\end{array}$ \\
\hline
\end{tabular}

Alterntif Chat Of Account yang Dapat Diterapkan di Gereja

\begin{tabular}{|c|c|c|c|}
\hline $\begin{array}{l}\text { Account } \\
\text { No }\end{array}$ & Parent & Account Name & Account Type \\
\hline & 1101 & KAS & \multirow{10}{*}{ Cash/Bank } \\
\hline 1101.001 & & Kas Perpuluhan & \\
\hline 1101.002 & & Kas Persembahan & \\
\hline 1101.003 & & Kas Pembanguan & \\
\hline 1101.004 & & $\begin{array}{l}\text { Kas Sie/Panitia Gereja (dapat disesuaikan dengan masing masing } \\
\text { bagian/ sie yang terdapat digereja) }\end{array}$ & \\
\hline \multirow[t]{2}{*}{1101.011} & & Kas Lainnya & \\
\hline & 1102 & Bank & \\
\hline 1102.001 & & Bank X1 Gereja & \\
\hline 1102.002 & & Bank X2 Gereja & \\
\hline \multirow[t]{2}{*}{1102.003} & & Bank Transfer (Pos Silang) IDR & \\
\hline & 1103 & Perlengkapan Gereja (Habis Pakai) & \multirow{2}{*}{$\begin{array}{l}\text { Other } \\
\text { Current } \\
\text { Asset }\end{array}$} \\
\hline 1103.001 & & Perlengkapan Gereja (ATK) & \\
\hline
\end{tabular}




\begin{tabular}{|c|c|c|c|}
\hline 1103.002 & & $\begin{array}{l}\text { Perlengkapan Alat Peraga Sekolah Minggu } \\
\text { (Sesuaikan perlengkapan yang terdapat digereja seperti alkitab dll) }\end{array}$ & \\
\hline & 1104 & Beban Dibayar diMuka & \\
\hline 1104.001 & & Sewa Dibayar Dimuka & \\
\hline 1104.002 & & Asuransi Dibayar Dimuka & \\
\hline \multirow[t]{2}{*}{1104.999} & & Beban Dibayar Dimuka Lain lain & \\
\hline & 1105 & Pesediaan & \multirow{3}{*}{ Inventory } \\
\hline 1105.001 & & Persediaan roti/anggur perjamuan & \\
\hline \multirow[t]{2}{*}{1105.002} & & Persediaan konsumsi & \\
\hline & 1201 & Aktiva Tetap & \multirow{10}{*}{ Fixed Asset } \\
\hline 1201.001 & & Tanah & \\
\hline 1201.002 & & Gedung & \\
\hline 1201.003 & & Kendaraan & \\
\hline 1201.004 & & Alat Musik (sebaiknya dipisahkan masing masing piano, gitar, dll) & \\
\hline 1201.005 & & Air Conditionner (AC) & \\
\hline 1201.006 & & Komputer & \\
\hline 1201.007 & & Kursi Meja & \\
\hline 1201.008 & & Perlengkapan Perjamuan Kudus & \\
\hline \multirow[t]{2}{*}{1201.009} & & Perlengkapan Pohon Natal dan Aksesoris & \\
\hline & 1202 & Akumulasi Depresiasi Aktiva Tetap & \multirow{4}{*}{$\begin{array}{l}\text { Accumulated } \\
\text { Depreciation }\end{array}$} \\
\hline 1202.001 & & Akumulasi Depresiasi Gedung & \\
\hline 1202.002 & & Akumulasi Depresiasi Kendaraan mobil & \\
\hline \multirow[t]{2}{*}{1202.003} & & Akumulasi Depresiasi disesuaikan dengan aktiva tetapnya & \\
\hline & 2104 & Hutang Gereja & \multirow{5}{*}{$\begin{array}{c}\text { Other } \\
\text { Current } \\
\text { Liability }\end{array}$} \\
\hline 2104.001 & & Utang Perpuluhan & \\
\hline 2104.002 & & Utang Persembahan & \\
\hline 2104.003 & & Utang Gaji & \\
\hline \multirow[t]{2}{*}{2104.004} & & Utang Bank & \\
\hline & 3100 & ASET NETO & \multirow{4}{*}{ Equity } \\
\hline 3100.001 & & Aset Neto Tidak Terikat & \\
\hline 3100.002 & & Aset Terikat Temporari & \\
\hline 3100.003 & & Aset Terikat Peranen & \\
\hline
\end{tabular}




\begin{tabular}{|c|c|c|c|}
\hline & 4101 & Pendapatan Utama & \multirow{14}{*}{ Revenue } \\
\hline 4101.001 & & Pendapatan Perpuluhan & \\
\hline 4101.002 & & Pendapatan Persembahan & \\
\hline 4101.003 & & Pendapatan Pembanguan & \\
\hline 4101.004 & & Pendapatan Kelompok Jemaat & \\
\hline 4101.005 & & $\begin{array}{l}\text { Pendapatan Sie/Panitia Gereja (dapat disesuaikan dengan masing } \\
\text { masing bagian/ sie yang terdapat digereja) }\end{array}$ & \\
\hline \multirow[t]{2}{*}{4101.999} & & Pendapatan Lainnya & \\
\hline & 4102 & Discount Pendapatan & \\
\hline \multirow[t]{2}{*}{4102.001} & & Diskon Pendapatan & \\
\hline & 4103 & Pengembalian Pendapatan & \\
\hline \multirow[t]{2}{*}{4103.001} & & Pengembalian Pendapatan & \\
\hline & 4104 & Setoran dari Cabang & \\
\hline 4101.001 & & Setoran dari Cabang XX1 & \\
\hline \multirow[t]{2}{*}{4101.002} & & Setoran Cabang Lainnya & \\
\hline & 6001 & Beban dan Biaya Administrasi & \multirow{17}{*}{ Expense } \\
\hline 6001.001 & & Tanda Kasih \& Tunj - Gembala Sidang (GS) & \\
\hline 6001.002 & & Tanda Kasih Sekpel. Gereja & \\
\hline \multirow[t]{2}{*}{6001.003} & & Tanda kasih Coster Gereja & \\
\hline & 6002 & Tunjangan Yang Dicadangkan & \\
\hline 6002.001 & & THR \& Kenaikan Jenjang Pendidikan Anak Gembala Sidang (GS) & \\
\hline 6002.002 & & THR Bpk. Pendeta & \\
\hline \multirow[t]{2}{*}{6002.003} & & THR Sekpel. Gereja & \\
\hline & 6003 & Iuran, Donasi dan Subsidi & \\
\hline 6003.001 & & Iuran Cabang Gereja XX1 & \\
\hline 6003.002 & & Iuran Lainnya & \\
\hline 6003.005 & & Donasi Paskah Cabang XX1 & \\
\hline 6003.006 & & Donasi Lainnya & \\
\hline 6003.009 & & Subsidi Cabang XX1 & \\
\hline \multirow[t]{2}{*}{6003.010} & & Subsidi Cabang lainnya & \\
\hline & 6004 & Beasiswa \& Bantuan Pendidikan di Sekolah Teologia & \\
\hline 6004.001 & & Biaya Beasiswa & \\
\hline
\end{tabular}




\begin{tabular}{|c|c|c|}
\hline 6004.002 & & Biaya Bantuan Study di Sekolah Teologia \\
\hline & 6005 & Persekutuan Hamba Tuhan dan Pegkhotbah Tamu \\
\hline 6005.001 & & Biaya Persekutuan Hamba Tuhan \\
\hline 6005.002 & & Biaya Seminar, Utusan, Pentahbisan Pdt. \\
\hline 6005.003 & & Biaya Akomodasi \& Tanda Kasih Pengkhotbah Tamu \\
\hline \multirow[t]{2}{*}{6005.004} & & Biaya lain lain \\
\hline & 6006 & Rumah Tangga Gereja dan Pastori \\
\hline \multirow[t]{2}{*}{6006.001} & & $\begin{array}{l}\text { Biaya Rumah Tangga Gereja Listrik, telepon, internet, perawatan } \\
\text { gereja dll (sebaiknya dipisahkan) }\end{array}$ \\
\hline & 6007 & Sekretaris Pelayanan \\
\hline 6007.001 & & Biaya Cetak Buletin \\
\hline \multirow[t]{2}{*}{6007.002} & & Biaya Cetak Kalender \\
\hline & 6008 & Sie Kelompok Pria \\
\hline \multirow[t]{2}{*}{6008.001} & & Biaya Lokalarya Kelompok Pria \\
\hline & 6009 & Sie Kelompok Wanita \\
\hline \multirow[t]{2}{*}{6009.001} & & Biaya Lokalarya Kelompok Wanita \\
\hline & 6010 & Sie Lanjut Usia (Lansia) \\
\hline \multirow[t]{2}{*}{6010.001} & & Biaya Transport Lansia \\
\hline & 6011 & Sie Persekutuan Kaum Muda Baptis (PKMB) \\
\hline \multirow[t]{2}{*}{6011.001} & & Biaya Lokakarya, Seminar Sie Pemuda \\
\hline & 6012 & Sie Sekolah Minggu (SM) \\
\hline \multirow[t]{2}{*}{6012.001} & & Biaya Transposrt SM \\
\hline & 6013 & Sie Pelayanan Anak \\
\hline \multirow[t]{2}{*}{6013.001} & & Biaya Lokakarya, Semir Sie Pelayanan Anak \\
\hline & 6014 & Sie Musik \\
\hline \multirow[t]{2}{*}{6014.001} & & Biaya Honor Pelatih Musik \\
\hline & 6015 & Sie Kematian dan Peralenan (KDP) \\
\hline 6015.001 & & Biaya Bantuan Sosial Kematian dan Uang Duka \\
\hline \multirow[t]{2}{*}{6015.002} & & Biaya Pengadaan Tanah Makam \\
\hline & 6017 & Sie Rumah Tangga dan Kunjungan (RTK) \\
\hline 6017.001 & & Biaya Bantuan Beasiswa Kepada Jemat \\
\hline 6017.002 & & Biaya Bantuan Natura (Sembako) Kepada Jemaat \\
\hline
\end{tabular}




\begin{tabular}{|l|l|l|l|} 
& $\mathbf{6 3 0 0}$ & Beban Depresiasi & \\
\hline 6300.001 & & Biaya Depresiasi Gedung & \\
\hline 6300.002 & & Biaya Depresiasi Kendaraan & \\
\hline 6300.003 & & $\begin{array}{l}\text { Biaya Depresiasi Keyboad } \\
\text { (biaya depersiasi disesuaikan dengan aktiva tetapnya) }\end{array}$ & \\
\hline & $\mathbf{6 4 0 0}$ & Beban \& Biaya Lain-lain & \multirow{2}{*}{$\begin{array}{c}\text { Other } \\
\text { Expense }\end{array}$} \\
\hline 6400.001 & & Biaya Administrasi Bank & \\
\hline 6400.002 & & Biaya Bunga Bank & \\
\hline 6400.003 & & Laba/Rugi Pelepasan Aktiva Tetap & \multirow{2}{*}{ Other Income } \\
\hline 6400.004 & & Biaya Pajak Bunga Bank \& Deposito & \\
\hline 6400.005 & & Biaya Pajak Bumi Dan Bangunan (PBB) & \\
\hline 6400.006 & & Biaya Pajak Kendaraan Bermotor (PKB) & \\
\hline & $\mathbf{7 1 0 0}$ & Pendapatan Lain-lain & Laba/Rugi dari Penilaian Kembali Aktiva Tetap \\
\hline 7100.001 & & &
\end{tabular}

\section{Alternatif Laporan Keuangan Gereja Laporan Aktivitas Gereja}

\section{Gereja XXX \\ Laporan Aktivitas \\ Untuk Tahun Yang Berakhir Tanggal 31 Desember XXXX}

\section{Perubahan Aset Neto Tidak Terikat :}

Pendapatan Dan Penghasilan

Pendapatan Utama

Pendapatan Perpuluhan

$\mathrm{XXX}$

Pendapatan Persembahan

$\mathrm{XXX}$

Pendapatan Pembanguan

$\mathrm{XXX}$

Pendapatan Masing-Masing Sie/Panitia Gereja (Dapat Disesuaikan

Dengan Masing Masing Bagian/ Sie Yang Terdapat Digereja)

XXX

Discount Pendapatan

Diskon Pendapatan

XXX

Pengembalian Pendapatan

Pengembalian Pendapatan

XXX

Setoran Dari Cabang

Setoran Dari Cabang XX

XXX

Total Pendapatan Dan Penghasilan

\section{Beban Dan Kerugian :}

Tanda Kasih \& Tunjangan Untuk Hamba Tuhan Dan Gereja 
Tanda Kasih \& Tunj - Gembala Sidang (GS) XXX

Tanda Kasih Sekpel. Gereja XXX

Tunjangan Yang Dicadangkan XXX

THR \& Kenaikan Jenjang Pendidikan Anak Gembala Sidang (GS)

THR Gembala Sidang (GS) XXX

THR Sekpel. Gereja $\quad$ XXX

Iuran, Donasi Dan Subsidi

Iuran Cabang XX XXX

Iuran Lainnya $\quad$ XXX

Donasi Paskah XXX

Donasi Natal Cabang XX XXX

Donasi Lainnya XXX

Subsidi Cabang XXX

Subsidi Cabang XX XXX

Subsidi Cabang Lainnya XXX

Beasiswa \& Bantuan Pendidikan Di STBI

Biaya Beasiswa XXX

Biaya Bantuan Study Di Sekolah Theologia XXX

Persekutuan Hamba Tuhan Dan Pegkhotbah Tamu

Biaya Persekutuan Hamba Tuhan $\quad$ XXX

Biaya Lain Lain $\quad$ XXX

Rumah Tangga Gereja Dan Pastori

Biaya Rumah Tangga Gereja Listrik, Telp, Internet XXX

Sekretaris Pelayanan

Biaya Cetak Buletin XXX

Sie (Sesuaikan Dengan Seluruh Akun Biaya Yang Terdapat

Diatas)

Biaya Lokalarya Kelompok Pria $\quad$ XXX

Beban \& Biaya Lain-Lain

Biaya Administrasi Bank XXX

Biaya Bunga Bank XXX

Laba/Rugi Pelepasan Aktiva Tetap XXX

Biaya Pajak Bunga Bank \& Deposito XXX

Biaya Pajak Bumi Dan Bangunan (PBB) XXX

Biaya Pajak Kendaraan Bermotor (PKB) XXX

Pendapatan Lain-Lain XXX

Laba/Rugi Dari Penilaian Kembali Aktiva Tetap XXX

Total Beban Dan Kerugian $\quad$ XXX

Total Perubahan Aset Neto Tidak Terikat $\quad$ XXX

Perubahan Aset Neto Terikat Temporer :

Pendapatan Perpuluhan Temporer $\quad$ XXX

Pendapatan Persembahan Temporer XXX

Pendapatan Pembanguan Temporer XXX

Kerugian Aktuarial Kewajiban Tahunan $\quad$ XXX 
Kenaikan/Penurunan Aset Neto Terikat Temporer

\section{Perubahan Aset Neto Terikat Permanen :}

Pendapatan Perpuluhan Permanen

$\mathrm{XXX}$

Pendapatan Persembahan Permanen

$\mathrm{XXX}$

Pendapatan Pembanguan Permanen

$\mathrm{XXX}$

Kerugian Lain Lain

$\mathrm{XXX}$

Kenaikan/Penurunan Aset Neto Terikat Permanen

$\mathbf{X X X}$

Kenaikan Aset Neto

Aset Neto Pada Awal Tahun

$X X X$

Aset Neto Pada Akhir Tahun

$\mathrm{XXX}$

$X X X$

Laporan Arus Kas Gereja

Laporan Posisi Keuangan (Neraca)

\section{Gereja Xxx}

Laporan Posisi Keuangan

31 Desember Xxxx

Tahun

20x2

20x1

Aset :

Kas :

Kas Perpuluhan

$\mathrm{Xxx} \quad \mathrm{Xxx}$

Kas Persembahan

$\mathrm{Xxx} \quad \mathrm{Xxx}$

Kas Pembanguan

$\mathrm{Xxx} \quad \mathrm{Xxx}$

Kas Sie/Panitia Masing-masing

$\mathrm{Xxx} \quad \mathrm{Xxx}$

Kas Lainnya

$\mathrm{Xxx} \quad \mathrm{Xxx}$

Bank :

$\mathrm{Xxx} \quad \mathrm{Xxx}$

Bank XX 1

Bank Transfer (Pos Silang) Idr

$\mathrm{Xxx} \quad \mathrm{Xxx}$

$\mathrm{Xxx} \quad \mathrm{Xxx}$

Aset Lancar :

Perlengkapan Gereja (Habis Pakai)

$\mathrm{Xxx} \quad \mathrm{Xxx}$

Beban Dibayar Dimuka

$\mathrm{Xxx} \quad \mathrm{Xxx}$

Sewa Dibayar Dimuka

$\mathrm{Xxx} \quad \mathrm{Xxx}$

Asuransi Dibayar Dimuka

$\mathrm{Xxx} \quad \mathrm{Xxx}$

Beban Dibayar Dimuka Lain Lain

$\mathrm{Xxx} \quad \mathrm{Xxx}$

Pesediaan Konsumsi Gereja (Roti Dan Anggur)

$\mathrm{Xxx} \quad \mathrm{Xxx}$

Aset Tetap :

Tanah

Gedung

$\mathrm{Xxx} \quad \mathrm{Xxx}$

Kendaraan

$\mathrm{Xxx} \quad \mathrm{Xxx}$

Akumulasi Depresiasi Aktiva Tetap

$\mathrm{Xxx} \quad \mathrm{Xxx}$

Akumulasi Depresiasi Gedung

$\mathrm{Xxx} \quad \mathrm{Xxx}$

Akumulasi Depresiasi Kendaraan

$\mathrm{Xxx} \quad \mathrm{Xxx}$

$\mathrm{Xxx} \quad \mathrm{Xxx}$ 


\begin{tabular}{|c|c|c|}
\hline Akumulasi Depresiasi Sesuaikan dengan COA & $\mathrm{Xxx}$ & $\mathrm{Xxx}$ \\
\hline Jumlah Aset & $\mathrm{Xxx}$ & $\mathrm{Xxx}$ \\
\hline Liabilitas Dan Aset Neto & $\mathrm{Xxx}$ & $\mathrm{Xxx}$ \\
\hline Liabilitas : & $\mathrm{Xxx}$ & $\mathrm{Xxx}$ \\
\hline Hutang Gereja & $\mathrm{Xxx}$ & $\mathrm{Xxx}$ \\
\hline Utang Perpuluhan & $\mathrm{Xxx}$ & $\mathrm{Xxx}$ \\
\hline Utang Persembahan & $\mathrm{Xxx}$ & $\mathrm{Xxx}$ \\
\hline Utang Gaji & $\mathrm{Xxx}$ & $\mathrm{Xxx}$ \\
\hline Utang Bank & $\mathrm{Xxx}$ & $\mathrm{Xxx}$ \\
\hline \multirow[t]{2}{*}{ Jumlah Liabilitas } & $\mathrm{Xxx}$ & $\mathrm{Xxx}$ \\
\hline & $\mathrm{Xxx}$ & $\mathrm{Xxx}$ \\
\hline Aset Neto : & $\mathrm{Xxx}$ & $\mathrm{Xxx}$ \\
\hline Tidak Terikat & $\mathrm{Xxx}$ & $\mathrm{Xxx}$ \\
\hline Terikat Temporer & $\mathrm{Xxx}$ & $\mathrm{Xxx}$ \\
\hline Terikat Permanen & $\mathrm{Xxx}$ & $\mathrm{Xxx}$ \\
\hline Jumlah Aset Neto & $\mathrm{Xxx}$ & $\mathrm{Xxx}$ \\
\hline Jumlah Liabilitas Dan Aset Neto & $\mathrm{XxX}$ & $\mathrm{Xxx}$ \\
\hline
\end{tabular}

\begin{tabular}{|lcc|}
\hline \multicolumn{1}{|c|}{$\begin{array}{c}\text { Gereja Xxx } \\
\text { Laporan Arus Kas }\end{array}$} & \\
Untuk Tahun Yang Berakhir Tanggal 31 Desember Xxxx & \\
\hline & Tahun \\
\hline Aliran kas dari Aktivitas Operasional : & $20 \mathrm{x} 2$ & $20 \mathrm{x} 1$ \\
Penerimaan : & & \\
Kas dari Perpuluhan & & \\
Kas dari Persembahan & $\mathrm{xxx}$ & $\mathrm{xxx}$ \\
Kas dari Pembanguna & $\mathrm{xxx}$ & $\mathrm{xxx}$ \\
Penerimaan Lainnya & $\mathrm{xxx}$ & $\mathrm{xxx}$ \\
& $\mathrm{xxx}$ & $\mathrm{xxx}$ \\
Pengeluaran : & & \\
Tanda Kasih \& Tunj - Gembala Sidang (GS) & & \\
Tanda Kasih Sekpel. Gereja & $\mathrm{xxx}$ & $\mathrm{xxx}$ \\
Tunjangan Yang Dicadangkan & $\mathrm{xxx}$ & $\mathrm{xxx}$ \\
THR Gembala Sidang (GS) & $\mathrm{xxx}$ & $\mathrm{xxx}$ \\
THR Sekpel. Gereja & $\mathrm{xxx}$ & $\mathrm{xxx}$ \\
Iuran Cabang XX & $\mathrm{xxx}$ & $\mathrm{xxx}$ \\
Iuran Lainnya & $\mathrm{xxx}$ & $\mathrm{xxx}$ \\
Donasi Natal Cabang XX & $\mathrm{xxx}$ & $\mathrm{xxx}$ \\
Donasi Lainnya & $\mathrm{xxx}$ & $\mathrm{xxx}$ \\
Subsidi Cabang XX & $\mathrm{xxx}$ & $\mathrm{xxx}$ \\
Subsidi Cabang Lainnya & $\mathrm{xxx}$ & $\mathrm{xxx}$ \\
& $\mathrm{xxx}$ & $\mathrm{xxx}$
\end{tabular}


Biaya Beasiswa

Biaya Bantuan Study di sekolah theologia

$\operatorname{XXX} \quad \mathrm{XXX}$

Biaya Persekutuan Hamba Tuhan

$\mathrm{XXX} \quad \mathrm{XXX}$

Biaya Lain Lain

$\mathrm{XxX} \quad \mathrm{XxX}$

$\mathrm{Xxx} \quad \mathrm{XxX}$

Biaya Rumah Tangga Gereja Listrik, Telp, Internet

$\mathrm{XXX} \quad \mathrm{XXX}$

Biaya Cetak Buletin

$\operatorname{xxx} \quad \mathrm{Xxx}$

Biaya Lokalarya Kelompok Pria

$\mathrm{xxx} \quad \mathrm{xxx}$

Biaya Administrasi Bank

$\mathrm{XxX} \quad \mathrm{XxX}$

Biaya Bunga Bank

$\mathrm{XXX} \quad \mathrm{XXX}$

Kas Neto yang diterima untuk Aktivitas Operasional

$\mathbf{X X X}$

$\mathbf{X X X}$

\section{Aliran Kas dari Aktivitas Investasi :}

Pembelian Aktiva tetap

Laba/Rugi Penilai Kembali Aktiva

$\mathrm{XXX} \quad \mathrm{XXX}$

Laba/Rugi Pelepasan Aktiva

$\mathrm{XxX} \quad \mathrm{XxX}$

Kas Neto yang Diterima untuk Aktivitas Inverstasi

$\mathrm{XXX} \quad \mathrm{XXX}$

$\mathbf{X X X} \quad \mathbf{X x X}$

\section{Aktivitas Kas dari Aktivitas Pendanaan}

Penerimaan dari Kontribusi lain :

XXX $\quad$ XXX

Kotak sukareka

$\mathrm{XXX} \quad \mathrm{XXX}$

Pendanaan lain :

Diakonia

$\mathrm{xxx} \quad \mathrm{xxx}$

Pendanaan ke cabang gereja $\mathrm{xxx}$

$\mathrm{XXX} \quad \mathrm{XXX}$

Kas Neto yang Diterima untuk Aktivitas Pendanaan

\begin{tabular}{|lcc|}
\hline Kenakan Neto Dalam Kas dan Setara Kas & $\mathrm{xxx}$ & $\mathrm{xxx}$ \\
Kas dan Setara Kas Awal tahun & $\mathrm{xxx}$ & $\mathrm{xxx}$ \\
Kas dan Setara Kas Akhir Tahun & $\mathrm{xxx}$ & $\mathrm{xxx}$ \\
\hline
\end{tabular}

\section{Simpulan}

Kesimpulan dari penelitian ini adalah :

1. Pemisahan tanggung jawab fungsional belum secara tegas diterapkan. 26 gereja pemisahan fungsi belum dilakukan secara jelas, sedangkan 12 gereja lainnya telah memisahkan tanggungjawab secara jelas.

2. Terdapat system wewenang dan prosedur pencatatan memadai. Hanya 5 gereja yang menerapkan pencatatan akuntansi secara lengkap mulai dari penggunaan jurnal, buku besar juga laporan keuangan yang dihasilkan gereja sesuai PSAK 45.

3. Pelaksanaan praktek yang sehat dalam menjalankan tugas dan fungsinya belum dapat dijalankan dengan baik karena sedikitnya jumlah pengurus gereja.

4. Karyawan belum memiliki mutu dan tanggung jawab yang sesuai, karena salut mencari orang yang memiliki komitmen dalam melakukan pelayanan digereja.

5. Penyusunan laporan keuangan gereja sebaiknya mengikuti pedoman dalam PSAK no.45.Untuk itu mendapatkan laporan keuangan yang baik perlu juga didukung dengan pengendalian internal yang memadahi. Pengendalian yang baik salah satunya dapat menggunakan sistem komputerisasi untuk mengurangi kecurangan yang terjadi. 


\section{Saran}

Saran untuk penelitian selanjutnya adalah:

1. Memisahkan jenis kelompok gereja sehingga dalam merancang pengendalian internal dan memberikan masukkan altrenatif perbaikan laporan keuangan dapat disesuaikan dengan karakteristik masing masing gereja tersebut.

2. Memambah jumlah objek penelitian untuk lebih dapat memetakan model pengendalian internal gereja, dan penerapan PSAK 45 sesuai karakteristik masing masing gereja.

3. Mengembangkan penelitian lebih lanjut dengan merancang system informasi akuntansi keuangan gereja kedalam system terkomputerisasi.

\section{Daftar Pustaka}

Adi, Priyo Hadi (dkk). 2020. "Penyusunan Laporan Keuangan gereja sesuai PSAK No. 45/2011: Pengabdian di Gereja Jemaat Kristus Indonesia Ekklesia Salatiga". Jurnal Magitrorum Et Scholarium, Volume 01No. 1Agustus 2020, 17 -24. https://ejournal.uksw.edu/jms/article/view/4432/1680

Ikatan Akuntansi Indonesia. 2011. PSAK No. 45. Revisi 2011. Dewan Standar Akuntansi Keuangan. Jakarta

Loen, Mishelei.2020.”Analisis Kinerja Keuangan GBI Bethany Depok Sebelum dan Sesudah Penerapan PSAKNo.45". Jurnal Akuntansi Dan Bisnis Krisnadwipayana. Vol. 7 $\begin{array}{lllllll}\text { No. } & 2 & \text { (Mei } \quad- & \text { Agustus) } & \text { 2020. } & \text { Hal } & \text { 1124. }\end{array}$ https://journal.unnes.ac.id/nju/index.php/jda/article/view/3242

Mamesah. 2013. "Penerapan PSAK No. 45 Pada GMIM Efrata Sentrum Sonder Dalam Kaitannya Dengan Kualitas Informasi Laporan Keuangan”. Jurnal Emba .Vol. 1 No. 4 Desember 2013. Universitas Sam Ratulangi, Manado. http://ejournal.unsrat.ac.id/index.php/emba/article/view/3368/2913. Hal 1717-1728.

Mulyadi. 2016. Sistem Akuntansi. Jakarta: Salemba Empat.

Tjungadi., "Rahadian. 2020. Akuntabilitas dan Penegndalian Internal Pelaporan Keuangan Pada Geraja Toraja ABC". Jurnal Akuntansi Riset (Aset).Vol 12 No.2. 2020. Hal. 241-264. https://ejournal.upi.edu/index.php/aset/article/view/24583

Wonok, Fredrik J."Penerapan PSAK No. 45 Tentang Pelaporan Keuangan Entitas Nirlaba Pada Jemaat GMIM Imanuel Leilem". Jurnal Emba. Vol. 4 No. 1 Maret 2016. Universitas Sam Ratulangi, Manado. Hal 202-213 https://ejournal.unsrat.ac.id/index.php/emba/article/view/11587

https://news.okezone.com/read/2019/01/12/340/2003419/diduga-gelapkan-dana-gantirugi-lahan-gereja-pendeta-di-perbatasan-dipenjara

BBC. 2018. Pengurus gereja Singapura yang 'korup' ditangkap ketika mau 'melarikan diri' https://www.bbc.com/indonesia/majalah43154207 
